\title{
Aktualisasi Moderasi Beragama di Lembaga Pendidikan
}

\section{Actualization of Religion Moderation in Education Institutions}

\author{
Edy Sutrisno \\ Penyuluh Agama Islam Fungsional Kementerian Agama Kabupaten Malang \\ Email: edyst99@gmail.com \\ Artikel diterima 14 Oktober 2019, diseleksi 30 November 2019, \\ dan disetujui 10 Desember 2019
}

Abstrak: Indonesia adalah negara majemuk yang terdiri dari suku, ras dan agama, yang berbeda-beda sehingga diperlukan toleransi dalam memahami semua perbedaan yang ada, begitu juga pada lembaga pendidikan kultur warganya juga beraneka ragam. Oleh sebab itu moderasi beragama sangat tepat sekali diterapkan dalam kehidupan berbangsa dan bernegara terutama pada masyarakat yang multikultural. Moderasi beragama sebagai jalan tengah dalam mengadapi perbedaan baik kelompok ekstrem maupun fundamental. Untuk menerapkan moderasi beragama dimasyarakat multikultural yang perlu dilakukan adalah; menjadikan lembaga pendidikan sebagai basis laboratorium moderasiberagama dan melakukan pendekatan sosio-religius dalam beragama dan bernegara

Kata Kunci: Moderasi Agama, Institusi, Pendidikan

Abstract:Indonesia is a pluralistic country consisting of different ethnicities, races and religions, so tolerance is needed in understanding all the differences that exist, as well as the cultural education institutions of its citizens are also diverse. Therefore religious moderation is very appropriate to be applied in national and state life, especially in multicultural societies, it is also expected that religious moderation is a middle way in dealing with 
differences in both extremes and fundamental groups. To implement religious moderation in multicultural societies, what needs to be done is; make educational institutions as a basis for religious moderation laboratories and take socio-religious approaches in religion and state.

Keywords:The Religion Moderation, Education Institution

\section{A. Pendahuluan}

Untuk saat ini dan ke depannya, gerakan moderasi beragama yang diusung oleh kementerian agama menemukan momentumnya.Framming moderasi beragama penting dalam mengelola kehidupan beragama pada masyarakat Indonesia yang plural dan multikultural.

Menariknya, ternyata semua agama yang diakui di Indonesia juga mengenal ajaran moderasi beragama.Dalam Islam misalnya, terdapat konsep washatiyah, yang memiliki padanan makna dengan kata tawassuth (tengahtengah), i'tidal (adil), dan tawazun (berimbang). Orangyang menerapkan prinsip wasathiyah bisa disebut wasith. ${ }^{1}$

Dalam tradisi Kristen, moderasi beragama menjadi cara pandang untuk menengahi ekstremitas tafsir ajaran Kristen yang dipahami sebagian umatnya. Salah satu kiat untuk memperkuat moderasi beragama adalah melakukan interaksi semaksimal mungkin antara agama yang satu dengan agama yang lain, antara aliran yang satu dengan aliran yang lain dalam internal umat beragama.

Moderasi beragama juga dapat dilihat dalam perspektif Gereja Katolik.Dalam Gereja Katolik istilah "moderat" tidak biasa. Yang dipakai adalah "terbuka" terhadap "fundamentalis" dan "tradisionalis" (yang menolak pembaruan dalam pengertian Gereja Katolik).

Adapun dalam tradisi Hindu, akar ruh moderasi beragama, atau jalan tengah, dapat ditelusuri hingga ribuan tahun ke belakang.Periode 
itu terdiri dari gabungan empat Yuga yang dimulai dari Satya Yuga, Treta Yuga, Dwapara Yuga dan Kali Yuga. Dalam setiap Yuga umat Hindu mengadaptasikan ajaranajarannya sebagai bentuk moderasi. Untuk mengatasi kemelut zaman dan menyesuaikan irama ajaran agama dengan watak zaman, moderasi tidak bisa dihindari dan menjadi keharusan sejarah.

Praktik agama yang dilaksanakan umat Hindu Indonesia pada zaman modern seperti sekarang ini adalah Puja Tri Sandhya dan Panca Sembah. Keduanya menjadi poros utama pembangunan peradaban Hindu Indonesia sejak terbentuknya Parisadha di tahun 1960an. Praktik kedua teologi ini berkelindan dengan banyak praktik agama Hindu lain. Seni dan ritual menjadi penunjang yang menyemarakkan Puja Tri Sandhya dan Panca Sembah.

Berkaitan dengan moderasi beragama, ajaran agama Hindu yang terpenting adalah susila, yaitu bagaimana menjaga hubungan yang harmonis antara sesama manusia, yang menjadi salah satu dari tiga penyebab kesejahteraan.Kasih sayang adalah hal yang utama dalam moderasi di semua agama.

Dalam Agama Budda esensi ajaran moderasi beragama dapat dilihat dari Pencerahan Sang Buddha yang berasal dari Sidharta Gautama. Ia mengikrarkan empat prasetya, yaitu berusaha menolong semua makhluk, menolak semua keinginan nafsu keduniawian, mempelajari, menghayati, dan mengamalkan Dharma, serta berusaha mencapai Pencerahan Sempurna.

Moderasi beragama juga mengakar dalam tradisi agama Khonghucu. Umat Khonghucu yang junzi (beriman dan luhur budi) memandang kehidupan ini dalam kaca mata yin yang, karena yin yang adalah filosofi, pemikiran dan spiritualitas seorang umat Khonghucu yang ingin hidup dalam dao. Yin yang adalah Sikap Tengah, bukan sikap ekstrem. Sesuatu yang kurang sama buruknya dengan suatu yang berlebihan. ${ }^{2}$ 
Indonesia harus memiliki cara berpikir dan bernarasi sendiri agar tidak terjebak dalam sekat ruang-ruang sosial. Pada titik ini, moderasi sosio-religius sebagai integrasi ajaran inti agama dan keadaan masyarakat multikultural di Indonesia dapat disinergikan dengan kebijakankebijakan sosial yang diambil oleh pemerintah negara. Kesadaran ini harus dimunculkan agar generasi bangsa ini bisa memahami bahwa Indonesia ada untuk semua.

Bahkan Menteri Agama Lukman Hakim Saifuddin, menetapkan tahun 2019 sebagai Tahun Moderasi Beragama Kementerian Agama. Pada saat yang sama, Perserikatan Bangsa-Bangsa juga menetapkan tahun 2019 sebagai Tahun Moderasi Internasional (The Internasional Year of Moderation). ${ }^{3}$

Lukman Hakim, menyerukan agar moderasi beragama menjadi arus utama dalam corak keberagamaan masyarakat Indonesia. Alasannya jelas, dan tepat, bahwa ber-agama secara moderat sudah menjadi karakteristik umat beragama di Indonesia, dan lebih cocok untuk kultur masyarakat kita yang majemuk. Ber-agama secara moderat adalah model beragama yang telah lama dipraktikkan dan tetap diperlukan pada era sekarang.

Apalagi belakangan ini, keragaman Indonesia sedang diuji, dimana sikap keberagamaan yang ekstrem diekspresikan oleh sekelompok orang atas nama agama, tidak hanya di media sosial, tapi juga di jalanan. Tidak hanya di Indonesia, bahkan dunia sedang menghadapi tantangan adanya kelompok masyarakat yang bersikap eksklusif, eskplosif, serta intoleran dengan mengatasnamakan agama. Sebagaimana yang telah tampak bahwa sekolah bagaikan ruang yang tak bertuan. Maksudnya, sekolah menjadi tempat bertarung ideologi transnasional yang kerap menafikan kebangsaan. Menyusup dalam benak pikiran peserta didik di dalam ruang kelas maupun di luar ruang kelas sehingga minimnya pemahaman kebangsaan dan menguatnya paham keagamaan yang formalis. Memahami agama dengan setengah-tengah dan mementingkan tampak luar dengan formalitas agama. 
Maka, menurut Lukman Hakim, moderasi beragama harus diejawantahkan dan bahkan dilembagakan dalam sistem dan struktur kerja satker-satker di Kementerian Agama agar ruhnya tidak melekat pada diri seorang Menteri Agama belaka, karena sepanjang keberadaannya, Kementerian Agama akan terus mendapatkan amanah untuk mengelola kehidupan keagamaan di Indonesia.

Dalam konteksi ini, narasi pentingnya jalan tengah (the middle path) dalam beragama seperti yang ditulis Fathorrahman Ghufron, Mengarusutamakan Islam Moderat, sesungguhnya memiliki nilai urgensinya untuk terus-menerus digaungkan oleh tokoh agama, akademisi kampus yang memiliki otoritas, dan melalui saluran berbagai media. Penggaungan narasi semacam itu khususnya untuk memberikan pendidikan kepada publik bahwa bersikap ekstrem dalam beragama, pada sisi manapun, akan selalu menimbulkan benturan.

Seruan moderasi agama juga belum lantang disuarakan oleh semua tokoh yang mewakili agama besar di Indonesia, sehingga lagi-lagi, narasi yang berkembang pun tidak berimbang. Kalau tradisi Islam menawarkan konsep wasatiyah sampai sekarang kita jarang mendengar konsep atau narasi tafsir moderate dalam tradisi-tradisi agama selain Islam. Akibatnya, seruan agar bersikap moderat sekarang ini seolah hanya ditujukan pada umat Islam.Ini yang akhirnya membawa kesan bahwa seolah hanya umat Islam yang tidak moderat dalam beragama, ekstrem, intoleran, radikal, dan ujung-ujungnya terlibat aksi terorisme. Narasi ekstremisme, intoleran, radikal, dan terorisme dalam media-media arus utama, misalnya, hampir tidak pernah disematkan pada aksi agresi Amerika Serikat dan Israel di Palestina, yang tindakannya juga sering melebihi batas moderat.

\section{B. Moderasi Beragama}

\section{Pengertian Moderasi Beragama}

Kata moderat dalam bahasa Arab dikenal dengan al-wasathiyah. Dalam Alquran merupakan kata yang terekam dari al-Qur'an surat al- 
Baqarah ayat: 143. Kata al-Wasath dalam ayat tersebut, bermakana terbaik dan paling sempurna.Dalam hadis yang sangat populer juga disebutkan bahwa sebaik-baikpersoalan adalah yang berada di tengah-tengah.Dalam artian melihat dan menyelesaikan satu persoalan, Islam moderat mencoba melakukan pendekatan kompromi dan berada di tengah-tengah, begitu pula dalam menyikapi sebuah perbedaan, baik perbedaan agama ataupun mazhab. Islam moderat selalu mengedepankan sikap toleransi, saling menghargai, dengan tetap meyakini kebenaran keyakinan masingmasing agama dan mazhab.Sehingga semua dapat menerima keputusan dengan kepala dingin, tanpa harus terlibat dalam aksi yanganarkis. ${ }^{4}$

Hashim Kamali, menegaskan bahwa moderate, tidak dapat dilepaskan dari dua kata kunci lainnya, yakni berimbang (balance), dan adil (justice). Moderat bukan berarti kita kompromi dengan prinsipprinsip pokok (ushuliyah) ajaran agama yang diyakini demi bersikap toleran kepada umat agama lain; moderat berarti "... confidence, right balancing, and justice..."5 Tanpa keseimbangan dan keadilan seruan moderasi beragama akan menjadi tidak efekti. Dengan demikian, moderat berarti masing-masing tidak boleh ekstrem di masing-masing sisi pandangnya.Keduanya harus mendekat dan mencari titik temu.

Selama ekstremitas ada di salah satu sisi, dan moderasi beragama tidak hadir, maka intoleransi dan konflik keagamaan tetap akan menjadi “bara dalam sekam", yang setiap saat bisa melesak, apalagi jika disulut dengan sumbu politik. Sebab, seperti ditegaskan Kamali di atas: "moderation is about pulling together the disparate centers than want to find a proper balance wherein people of different cultures, religions and politics listen to each other and learn how to work out their differences" 6

Moderasi adalah ajaran inti agama Islam.Islam moderat adalah paham keagamaan yang sangat relevan dalam konteks keberagaman dalam segala aspek, baik agama, adat istiadat, suku dan bangsa itu sendiri.Tak pelak lagi, ragam pemahaman keagamaan adalah sebuah fakta sejarah dalam Islam. Keragaman tersebut, salah satunya, disebabkan oleh dialektika 
antara teks dan realitas itu sendiri, dan cara pandang terhadap posisi akal dan wahyu dalam menyelesaikan satu masalah. Konsekuensi logis dari kenyataan tersebut adalah munculnya terma-terma yang mengikut di belakang kata Islam. Sebut misalnya, Islam Fundamental, Islam Liberal, Islam Progresif, Islam Moderat, dan masih banyak label yanglain.

Di dalam al-Quran terdapat beberapa ayat yang menunjukkan misi agama Islam, karakteristik ajaran Islam, dan karakteristik umat Islam. Misi agama ini adalah sebagai rahmat bagi semesta alam (rahmatan lil 'alamin), QS.al-Anbiya': 107. Adapun karakteristik ajaran Islam adalah agama yang sesuai dengan kemanusiaan (fitrah), QS.al-Rûm: 30, sedangkan karakteristik umat Islam adalah umat yang moderat (ummatan wasatan), QS. Al-Baqarah: 143. Di samping itu, terdapat pula ayat yang memerintahkan agar umat Islam berpihak kepada kebenaran (hanîf), QS.al-Rûm: 30, serta menegakkan keadilan (QS. al-Maidah: 8) dan kebaikan agar menjadi umat terbaik (khair ummah), QS. Ali 'Imrân: 110. Ayat-ayat tersebut memperkuat perlunya beragama dengan sikap moderat (tawassuth) yang digambarkan sebagai umatan wasathan, sehingga pada saat ini banyak ulama mempromosikan konsep moderasi Islam (wasathiyyah al-Islâm). Memang ada juga kelompok-kelompok Islam yang tidak setuju dengan konsep moderasi ini, karena ia dianggap menjual agama kepada pihak lain.

Salah satu di antara ulama yang banyak menguraikan tentang moderasi adalah Yusuf al-Qaradhawi. Dia adalah seorang tokoh ikhwan moderat dan sangat kritis terhadap pemikiran Sayyid Quthb, yang dianggap menginspirasi munculnya radikalisme dan ektrimisme serta paham yang menuduh kelompok lain sebagai thâghht atau kafir takfiri. Dia pun mengungkapkan bahwa rambu-rambu moderasi ini, antara lain: (1) pemahaman Islam secara komprehensif, (2) keseimbangan antara ketetapan syari'ah dan perubahan zaman, (3) dukungan kepada kedamaian dan penghormatan nilai-nilai kemanusiaan, (4) pengakuan akan pluralitas agama, budaya dan politik, dan (5) pengakuan terhadap hak-hak minoritas. ${ }^{7}$ 
Karena moderasi ini menekankan pada sikap, maka bentuk moderasi ini pun bisa berbeda antara satu tempat dengan tempat lainnya, karena pihak-pihak yang berhadapan dan persoalan-persoalan yang dihadapi tidak sama antara di satu negara dengan lainnya. Di negara-negara mayoritas Muslim, sikap moderasi itu minimal meliputi: pengakuan atas keberadaan pihak lain, pemilikan sikap toleran, penghormatan atas perbedaan pendapat, dan tidak memaksakan kehendak dengan cara kekerasan. Hal ini berdasarkan pada ayat-ayat al-Quran, antara lain menghargai kemajemukan dan kemauan berinteraksi (QS. al-Hujurât: 13), ekspresi agama dengan bijaksana dan santun (QS. al-Nahl: 125), prinsip kemudahan sesuai kemampuan (QS. al-Baqarah: 185, al-Baqarah: 286 dan QS. al-Taghâbun: 16).

Kriteria dasar tersebut sebenarnya bisa juga dipergunakan untuk mensifati muslim moderat di negara-negara minoritas muslim, walaupun secara implementatif tetap ada perbedaan, terutama terkait dengan hubungan antara agama dan negara. Di negara-negara minoritas muslim seperti Amerika, John Esposito dan Karen Armstrong, seperti dituturkan oleh Muqtadir Khan, mendeskripsikan muslim moderat sebagai orang yang mengeskpresikan Islam secara ramah dan bersedia untuk hidup berdampingan secara damai dengan pemeluk agama lain serta nyaman dengan demokrasi dan pemisahan politik dan agama. ${ }^{8}$

Moderasi beragama harus dipahami sebagai sikap beragama yang seimbang antara pengamalan agama sendiri (eksklusif) dan penghormatan kepada praktik beragama orang lain yang berbeda keyakinan (inklusif). Keseimbangan atau jalan tengah dalam praktik beragama ini niscaya akan menghindarkan kita dari sikap ekstrem berlebihan, fanatik dan sikap revolusioner dalam beragama. Seperti telah diisyaratkan sebelumnya, moderasi beragama merupakan solusi atas hadirnya dua kutub ekstrem dalam beragama, kutub ultrakonservatif atau ekstremkanan disatu sisi, dan liberal atau ekstrem kiri disisi lain.

Moderasi beragama sesungguhnya merupakan kunci terciptanya toleransi dan kerukunan, baik ditingkat lokal, nasional, maupung lobal. 
Pilihan pada moderasi dengan menolak ekstremisme dan liberalisme dalam beragama adalah kunci keseimbangan, demi terpeliharanya peradaban dan terciptanya perdamaian. Dengan cara inilah masingmasing umat beragama dapat memperlakukan orang lain secara terhormat, menerima perbedaan, serta hidup bersama dalam damai dan harmoni. Dalam masyarakat multikultural seperti Indonesia, moderasi beragama bisa jadi bukan pilihan, melainkan keharusan. ${ }^{9}$

\section{Jejak Moderasi Islam Ditinjau dalam Berbagai Persepektif}

Islam pada dasarnya adalah agama universal, tidak terkotak-kotak oleh label tertentu, hanya saja, cara pemahaman terhadap agama Islam itu kemudian menghasilkan terma yang berbeda. Diterima atau tidak, itulah fakta yang ada dewasa ini yang mempunyai akar sejarah yang kuat dalam khazanah Islam. Fakta sejarah menyatakan bahwa embrio keberagamaan tersebut sudah ada sejak era rasulullah, yang kemudian semakin berkembang pada era sahabat, terlebih khusus pada era Umar bin Khattab. Oleh karena itu, paham Islam moderat merupakan ajaran yang mesti dibumikan di nusantara.Ia sangat representatif memberikan jawaban dan solusi terhadap seluruh permasalahan yang dihadapi umat Islam dewasa ini. Ia tidak terlalu ekstrim kekanan, dalam hal ini overtekstual, tapi juga tidak terlalu ekstrim kekiri, dalam artian overkonstekstual.

Kemoderatan Islam tersebut kemudian terekam juga dalam berbagai disiplin ilmu; akidah, fiqih, tafsir, pemikiran, tasawuf dan dakwah.

\section{a. Moderasi Akidah Islam}

Dalam ilmu akidah (teologi), Islam moderat direpsentasikan oleh aliran al-asy'ariyah.Aliran yang menengahi antara muktazilah yang sangat rasional dengan salafiah dan hanabilah yang sangat tekstual.Keduanya sama-sama berada pada titik ekstrim.muktazilah dianggap ekstrim dalam memosisikan akal di atas segalanya. Dalam pengambilan kesimpulan banyak menggunakan premis-premis demonstrative yang bersifat logis.Sebaliknya, kaum salafiah dan hanabilah berada pada titik yang 
berseberangan.Mengutamakan teks dan seringkali dalam beberapa kasus dia mengabaikan penggunakan akal dalam memahami teks tersebut. Akibat dari keduanya sama-sama kurang mewakili dan menggambarkan ajaran Islam yang selama ini dikenal dengan penuh keseimbangan. Rasionalitas yang berlebihan seringkali mengaburkan kejernihan akidah Islam, sebaliknya tekstualitas yang berlebihan bisa saja menyebabkan kejumudan dalam berijtihad.

Bentuk moderasi aliran kalam asy'ariyah dapat dilihat dalam beberapa pandangannya terkait dengan persoalan dan perdebatan teologis. Misalnya perdebatan isu kalamullah dalam pada itu, terjewantahkan dalam perdebatan hakekat Al-Quran antara kelompok hanabilah dan muktazilah. Kelompok hanabilah menyatakan dengan tegas bahwa Alquran adalah bukan makhluk, ia adalah Qadim dan Azali. Sementara muktazilah menyatakan bahwa al-Qur'an adalah makhluk, ${ }^{10}$ karena ia tersusun dari suara dan huruf yang dibaca yang notabene sudah terjadi proses transmisi dan adaptasi dengan karya karsa manusia. ${ }^{11}$ Perdebatan yang panjang antar kelompok tersebut menyebabkan fitnah bagi umat Islam. Dalam sejarahnya, Ahamd bin Hanbal diperjara oleh pemerintah yang didominasi oleh para penganut muktazilah, dengan asumsi bahwa dia menentang pemerintah atas pendapatnya tentang al-Qur'an yang berlainan denganmuktazilah.

\section{b. Moderasi Hukum Islam}

Kemoderatan Islam pun harus digalakkan dalam hukum, dalam hal ini, dialektika antara teks dan realitas selalu berjalan lurus dalam mengeluarkan sebuah hukum, karena maksud Tuhan yang tertuang dalam al-Qur'an dan hadis tak pernah bersebrangan dengan kemaslahatan umat manusia.Hasil ijtihad para ulama fuqaha yang melahirkan sebuah hukum sejatinya tetap harus memerhatikan prinsip fleksibilitas (almurunah). Karena pada hakekatnya tidak bisa dipungkiri bahwa sebuah hukum senantiasa lahir dari pergumulan sosial kemasyarakatan yang sangat dinamis.Konsekuensi logis dari fakta ini adalah sebuah hukum 
bisasaja berubah dengan berubahnya konteks kemasyarakatan dimana hukum itu hendakdiaplikasikan.

Sebagiaman yang dirumuskan oleh Muhammad Rauf Amin bahwa karakteristik moderasi hukum Islam dapat dipetakan dalam tiga karakter.

Pertama, subatansialisasi teks atau hukum, yang dimaksud dengan subtansialisasi teks adalah adanya kesadaran dan pengakuan bahwa dibalik sebuah teks atau hukum ada tujuan hukum (maqsad) yang menjadi pesan utama bagi manusia.Bagi seorang mujtahid atau para fuqaha sejatinya senantiasa memerhatikan tujuan hukum itu dalam tiap menelorkan sebuah hukum dari teks.Ia harus menyelami makna yang terdalam di balik teks atau ayat tertentu.Ia tidak boleh hanya memahami secara sepintas dan jumud pada permukaan teks. Memahami maksud atau tujuan hukum itu adalah hal yang sangat mendasar yang perlu dihadirkan sebagai sesuatu yang paling penting dari sekedar pemahamanlahir.

Kedua, kontekstualisasi, adalah kontekstualisasi teks atau hukum. Jika yang subtansialisasi melacak tujuan hukum di balik teks, maka karakter yang kedua ini lebih pada upaya melacak historitas teks (unsure kesejarahan sebuah teks)yang melingkupinya yang pada gilirannya memberi pengaruh pada lahirnya sebuah hukum.Teori ini berasumsi bahwa sebauh hukum boleh jadi ditetapkan oleh Allah atau nabi dikarenakan oleh sebauh kondisi atau keadaan yang menghendaki adanya hukum tersebut. Dalam artian bahwa bila kondisi yang menjadi pengaruh lahirnya teks tersebut berubah atau tidak ada lagi, maka seharusnya hukum yang dilahirkan dari sebuah teks tersebut juga berubah atau digantikan oleh hukum yang lain. Dengan demikian, teori kontektualisasi ini sangat penting untuk dipahami oleh semua pakar hukum sebelum melahirkan sebuah produk hukum dalam masyarakat.

Ketiga, rasionalisasi teks, karakter yang ketiga ini juga sangat penting untuk diketahui oleh seluruh pakar hukum dan mujtahid.Rasionalisasi teks bermakna bahwa tiap teks hukum memiliki illat yang merupakan 
dasar dan sebab adanya sebuah hukum. Proses rasionalisasi itu sendiri adalah upaya untuk melacak dan menentukan faktor-faktor yang mempengaruhi ada atau tidak adanya sebuah hukum yang terkandung dalam sebuah teks. Dalam bahasa lain para pakar sering memaknainya dengan kata illat hukum. Illat hukum berbeda dengan hikmah sebuah hukum yang justru dipahami sebagai padanan arti subtansialisasi. Untuk membedakan keduanya akan dilihat dalam sebuah contoh konkrit, yaitu kebolehan untuk melakukan jama dan qashar bagi musafir. Jama dan qashar itu dibolehkan bagi musafir karena adanya kesulitan (masyaqqah) yang terkadung dalam perjalanan.Dalam analisa kasus ini dapat dilihat dengan dua pandangan.Mengaitkan adanya keringanan jamadan qashar karena perjalanan berarti yang terjadi adalah rasionalisasi, sementara jika jama dan qashar itu dihubungkan dengan adanya kesulitan (masyaqqah) maka yang terjadi adalah subtansialisasi. ${ }^{12}$

\section{c. Moderasi Penafsiran}

Seorang penafsir harus mampu melahirkan produk tafsir yang moderat dan berkerahmatan.Tafsir moderat yang berkerahmatan yang dimaksud adalah produk tafsir yang sesuai dengan nilai-nilai keislaman yang tetap memerhatikan kondisi sosial kemasyarakatan di nusantara yang sangat majemuk dan hiterogen. Tafsir yang tidak hanya mengcover satu kepentingan saja, tapi lebih pada produk tafsir yang dapat membawa rahmat bagi seluruh masyarakat Indonesia, tanpa melihat dari suku dan agama. Karena pada hakekatnya, Islam datang bukan hanya untuk umat Islam saja, tapi untuk seluruh manusia.

Untuk melahirkan produk tafsir yang moderat seperti yang digambarkan di atas mengharuskan adanya pembaharuan (tajdid) dalam penafsiran, baik dalam aspek metodologi maupun aspek tema yang sesuai dengan konteks masyarakat Indonesia. Dalam poin ini, seorang mufassir selain harus menguasai ilmu-ilmu wajib terkait dengan penfasiran, seperti bahasa Arab, asbab nuzul, ushul tafsir dan ilmu al-Qur'an juga dituntut memiliki wawasan dan keilmuan yang terkait dengan fenomena 
sosial yang terjadi di masyarakat nusantara. Hanya dengan itu, produk tafsir yang dilahirkan para mufassir dapat memberikan sumbangsih nyata terhadap persoalan kemanusiaan yang dihadapi oleh masyarakat modern, khususnya diNusantara.

Menurut Wasfi 'Asyur, al-tafsir al-maqashid adalah salah satu corak tafsir yang pemaknannya mengarah pada visi al-Qur'an, baik universal maupun parsial, yang bertujuan untuk mewujudkan kemaslahatan manusia. Al-Atrash dan Abd Khalid, memandang tafsir maqhasidi sebagai salah satu bentuk penafsiran yang dilakukan dengan cara menggali makna yang tersirat dalam lafadz-lafadz al-Qur'an dengan mempertimbangkan tujuan yang terkandung di dalamnya. ${ }^{13}$

Sedangkan menurut Jaser Auda secara sederhana mengatakan bahwa tafsir maqhasidi adalah tafsir yang mempertimbangkan faktor maqasid yang berdasar pada persepsi bahwa al-Qur'an merupakan suatu keseluruhan yang menyatu. Sehingga sejumlah kecil ayat yang berhubungan dengan hukum akan meluas dari beberapa ratus ayat menjadi seluruh teks alQur'an. Surah dan ayat al-Qur'an yang membahas tentang keimanan, kisah para nabi, kehidupan akhirat dan alam semesta, seluruhnya menjadi bagian dari sebuah gambaranutuh. ${ }^{14}$

\section{d. Moderasi PemikiranIslam}

Sementara, sisi kemoderatan dalam pemikiran Islam adalah mengedepankan sikap toleran dalam perbedaan. Keterbukaan menerima keberagamaan. Baik beragam dalam mazhab maupun beragam dalam beragama. Perbedaan tidak menghalangi untuk menjalin kerja sama, dengan asas kemanusiaanMeyakini agama Islam yang paling benar, tidak berarti harus melecehkan agama orang lain. Sehingga akan terjadilah persaudaraan dan persatuan anatar agama, sebagaimana yang pernah terjadi di Madinah di bawah komando RasulullahSaw.

Dalam pandangan Alwi Shihab bahwa konsep islam inklusif adalah tidak hanya sebatas pengakuan akan kemajemukan masyarakat, tapi 
juga harus diaktualisasikan dalam bentuk keterlibatan aktif terhadap kenyataan tersebut. ${ }^{15}$ Dalam artian bahwa sikap inklusivisme yang dipahami dalam pemikiran Islam adalah memberikan ruang bagi keragaman pemikiran, pemahaman dan perpsepsi keislaman. Bahkkan paham ini menganggap kebenaran tidak hanya terdapat dalam satu kelompok saja, melainkan juga ada pada kelompok yang lain, termasuk kelompok agam sekalipun.Pemahaman ini berangkat dari sebuah keyakinan bahwa pada dasarnya semua agama membawa ajaran kesalamatan. Perbedaan dari satu agama yang dibawah seorang nabi dari generasi ke generasi hanyalah syariatsaja.

Mengacu pada paradigma seperti di atas, maka pada gilirannya akan membuka interaksi positif dan dialog antar agama-agama. Baik muslim maupun agama yang lainnya berkewajiban untuk menegakan syariat agama masing-masing. Dengan adanya sifat terbuka seperti itu, akan melahirkan keharmonisan di tengah masyarakat sehingga tiap orang melibatkan diri dalam bentuk sikap toleransi terhadap perbedaan keyakinan, serta menghindarkan diri dari sikap membenarkan diri sendiri dan secara ekstrem menyalahkan orang lain. ${ }^{16}$

Lebih pada itu, sikap moderat dalam bingka pemikiran Islam adalah memberikan jaminan seluas-luasnya terhadap perlindungan nilai-nilai kemanusiaan. Dalam bahasa lain bahwa peradaban manusia itulah yang paling tinggi yang perlu dijunjung tinggi bersama oleh semua kelompok, tanpa melihat agama, ras, dan suku. Semuanya harus menjaga dan memperjuangkan nilai kemanusiaan. Dengan demikian, semua umat manusia atau umat beragama diarahkan untuk dapat hidup berdapingan, dan menjauhi segala bentuk kebencian dan permusuhan. Di saat yang sama nilai-nilai universal seperti keadilan, kebebasan, dan persamaan harus dijunjung tinggi, kerena pada hekakatnya ketiga hal tersebut merupakan ajaran yang sangat mulia dan merupakan inti dari peradaman kemanusian.

Inklusiviseme juga tidak berarti bahwa tiap penganut agama memiliki kebabasan untuk pindah dan gonta-ganti agama, atau menyatakan 
bahwa pemeluk agama tertentu agakan kehilangan jati diri. Tidak sama sekali. Tapi sikap insklusivisme dalam beragama lebih pada menerima dan menyadari kehadiran agama lain dalam kehidupan berasama dan bernegara, sehingga kita dapat hidup berdampingan, sekalipun berbeda dalam hal keyakinan.

\section{e. Tasawuf Moderat}

Selain moderasi dalam pemikiran, Islam Moderat juga nampak dalam wilayah tasawuf. Dalam pada itu, konsep ajaran esoterik yang termanifestasi dalam spritual sufistik tidak berarti negatif sebagaimana banyak dipahami orang. Ajaran spiritual sufistik tidak berarti kekumuhan, kekurangan, kemiskinan dan lain-lain, tapi sufi moderat adalah orang yang selalu menghadirkan nilai-nilai ketuhanan dalam tiap langkahnya. Praktik kehidupan spiritualitas sufistik moderat adalah membangun kehidupan yang penuh dengan kebahagiaanyaitu;kebahagiaanqalbiyahyaknidengan makrifatullah melalui akhlak karimah, serta kebahagian jasminiah dengan kesehatan serta pemenuhan kebutuhan yang bersifat material.

Selain itu, konsep tasawuf yang moderat adalah tasawuf yang hadir sebagai jawaban terhadap serangan kepada tasawuf yang sama-sama berada pada posisi berlebihan.Sebagaimana dijelaskan sebelumnya bahwa pada periode tertentu konsep tasawuf yang banyak dikenal di masyarakat terkesan pasif dan pasrah bahkan meninggalkan segala yang berkaitan dengan dunia melalui konsep zuhudnya. Konsekuensinya adalah tuduhan negatif terhadap tasawuf sebagai salah satu penyebab utama terjadinya kemunduran dalam masyarakat muslim. Di sisi lain, dalam periode tertentu ajaran tasawuf juga pernah melewati fase yang sangat ekstrim terhadap konsep ketuhanan. Di antaranya adalah konsep yang menyatakan bahwa, yang disembah dan yang menyembah adalah satu. Konsep yang dipopulerkan oleh Al-Hallaj tersebut kemudian mendapat kritikan dari para ahli fuqaha dan dianggap sebagai paham yangmenyimpang. ${ }^{17}$ 
Berangakat dari fakta sejarah tersebut, sejatinya tasawuf moderat dapat menjadi pilihan terlebih lagi dalam konteks manusia modern yang sangat rapuh secara spiritual. Tasawuf moderat dalam konteks sekarang harus dipahami secara dinamis dan faktual.Salah satunya adalah konsep zuhud tidak terkesan negative seperti pasrah dan kumuh, tapi lebih pada sebuah kondisi jiwa yang tidak menggantungkan diri atau kebahagian pada dunia. Meskipun pada saat yang sama, juga tidak meninggalkan dunia. Dalam sebuah ungkapan Ali ibn Thalib, Ya Allah letakkan dunia hanya pada kedua tanganku, jangan Engkau letakkan pada hatiku. Pemahaman seperti itu, tersirat bahwa seorang sufi atau pelaku tasawuf tetap aktif dan optimis dalam melaksanakan fungsinya didunia ini dengan baik. Misalnya, seorang petani tetap bertani dengan sungguh-sungguh. Seorang pegawai tetap disiplin dan bekerja secara professional, tapi semuanya itu dibarengi dengan kekuatan sprirual yang tinggi, sehingga semua tetap berada pada koridor yang sesuai dengan ajaranIslam.

Tasawuf moderat juga tidak meyakini bahwa, yang menyembah dan yang disembah adalah satu. Wujud keduanya tetap berbeda. Hanya saja, seorang hamba hidup dengan penuh kesadaran ketuhanan, di antaranya adalah berupaya untuk menampakkan sifat-sifat Allah dalam bentuk perbuatan dan sifat sehari-hari. Dalam konteks ini, manusia modern banyak yang kehilangan kesadaran ketuhanan. Bahkan ada kecenderungan untuk melakukan 'sekularisasi kesadaran'. Yaitu pencapaian yang luar biasa baik dalam aspek ilmu pengetahuna, industry maupun teknonologi, akan tetapi pencapaian tersebut tidak sama sekali menghasilkan kepuasan batin atau kebahagian sejati. Yang ada adalah kekeringan spiritual. Akibatnya, segala pencapaian manusia modern tidak sama sekali mengantarkannya pada sebuah kebahagian diri dan kedamaian pada lingkungan, tapi justru sebaliknya prestasi tersebut justru membawa malapetaka terhadap dirinya dan kemanusian itusendiri. 


\section{f. Tasawuf Moderat}

Islam moderat juga tampak dalam wilayah tasawuf, konsep ajaran esoterik yang termanifestasi dalam spritual sufistik tidak berarti negatif sebagaimana banyak dipahami orang. Ajaran spiritual sufistik tidak berarti kekumuhan, kekurangan, kemiskinan dan lain-lain, tapi sufi moderat adalah orang yang selalu menghadirkan nilai-nilai ketuhanan dalam tiap langkahnya. Praktik kehidupan spiritualitas sufistik moderat adalah membangun kehidupan yang penuh dengan kebahagiaanyaitu; kebahagiaan qalbiyah yakni dengan makrifatullah melalui akhlak karimah, serta kebahagiaan jasminiah dengan kesehatan serta pemenuhan kebutuhan yang bersifat material.

Berangakat dari fakta sejarah tersebut, sejatinya tasawuf moderat dapat menjadi pilihan terlebih lagi dalam konteks manusia modern yang sangat rapuh secara spiritual.Tasawuf moderat dalam konteks sekarang harus dipahami secara dinamis dan faktual. Salah satunya adalah konsep zuhud tidak terkesan negatif seperti pasrah dan kumuh, tapi lebih pada sebuah kondisi jiwa yang tidak menggantungkan diri atau kebahagian pada dunia. Meskipun pada saat yang sama, juga tidak meninggalkan dunia. Pemahaman seperti itu, tersirat bahwa seorang sufi atau pelaku tasawuf tetap aktif dan optimis dalam melaksanakan fungsinya didunia ini dengan baik. Misalnya, seorang petani tetap bertani dengan sungguh-sungguh. Seorang pegawai tetap disiplin dan bekerja secara professional, tapi semuanya itu dibarengi dengan kekuatan sprirual yang tinggi, sehingga semua tetap berada pada koridor yang sesuai dengan ajaranIslam.

\section{g. Moderasi Dakwah Islamiyah}

Amar ma'ruf dan nahi munkar adalah syiar agama yang paling mulia setelah tauhid. Seluruh nabi dan rasul diutus oleh nabi tugasnya adalah untuk melakukan amar ma'ruf dan nahi munkar, atau bahasa lain berdakwa di jalan Allah SWT Dalam al-Qur'an Allah SWT. Yang artinya:Kamu adalah umat terbaik yang dilahirkan untuk manusia, 
menyuruhkepadaamarma'rufdanmencegahdariyangmunkardan beriman kepada Allah. Sekiranya ahli kitab beriman, tentulah itu lebih baik bagi mereka; di antara mereka ada yang beriman dan kebanyakanmerekaadalahorang-orangyangfasik (Q.S. Ali Imran: 110).

Berdasarkan dari ayat di atas, dapat dipahami bahwa tugas dakwah adalah amanah yang paling mulia.Maka dari itu, seorang da'i harus benar-benar memahami aspek-aspek penentu dalam kesuksesan sebuah dakwah.Tidak asal dakwah itu disampaikan. Seorang da'i sejatinya memerhatikan prinsip-prinsip dakwah seperti strategi dakwah, metode dakwah, dan sasarandakwah.

Strategi dakwah yang baik adalah dakwah yang senantiasa memerhatikan ketepatan sasaran dakwah atau mitra dakwah. Sangat penting bagi seorang da'i mengetahui secara baik masyarakat sebagai sasaran dakwah, baik dari aspek budaya, adat istiadat, pengetahuan dan bahkan aspek ekonomi. Tiap kondisi tersebut mengharuskan strategi khusus yang sesuai dengan kondisinya masing-masing.

Perkembangan teknologi komunikasi telah mengubah cara orang berkomunikasi. Saat ini, hampir setiap orang menggunakan internet dalam mengirim, mencari, dan membaca informasi.Dalam berinteraksi pun kebanyakan melalui media sosial dibanding komunikasi secara langsung. Hal ini sangat dimungkinkanterjadi setidaknya dipengaruhi beberapa faktor, antara lain pesatnya perkembangan teknologi informasi dan komunikasi, juga kecenderungan masyarakat milenial yang sangat bergantung pada media.

Kaitannya dengan dakwah, peran media sangat strategis dalam upaya penyampaian pesan dakwah.Media mampu menembus batas-batas ruang dan waktu.Artinya, meski dengan jarak jauh komunikasi memungkinkan dilakukan.Tidak hanya itu, media juga menawarkankecepatan waktu dalam menyediakan beragam informasi.Media saat ini tumbuh kian pesat. Dulu, media elektronik seperti televisi dan radio menjadi pilihan favorit dalam mencari informasi.Keunggulannya adalah mampu mengirim 
pesan suara dan gambar (visual).Saat ini realita itu mulai bergeser, publik tidak lagi berpusat pada media elektronik sebagai sumber informasi. Justru, kecenderungannya saat ini beralih ke new media(internet).

\section{Praktik Moderasi Beragama pada Masyarakat Multikultural}

\section{Menjadikan Lembaga Pendidikan Sebagai Basis Laboratorium Moderasi Beragama}

Lembaga pendidikan sangat tepat menjadi "laboratorium moderasi beragama".Seperti yang telah dipahami bahwa bangsa Indonesia merupakan bangsa yang memiliki ragam suku dan agama.Indonesia memiliki kekhasan yang unik, tetapi penuh dengan tantangan.sekolah sebagai institusi pendidikan dapat menumbuhkan pola pikir moderasi beragama dengan kondisi bahwa pandangan eksklusif dan tindakan ekstremisme kekerasan dalam jubah agama akan merusak sendi serta tenun kebangsaan yang majemuk.

Di sinilah pentingnya "batu pertama" moderasi beragama dibangun atas dasar filosofi universal dalam hubungan sosial kemanusiaan. Lembaga pendidikan menjadi sarana tepat guna menyebarkan sensitivitas peserta didik pada ragam perbedaan. Membuka ruang dialog, guru memberikan pemahaman bahwa agama membawa risalah cinta bukan benci dan sistem di sekolah leluasa pada perbedaan tersebut.Tidak hanya itu, rekomendasi yang dikeluarkan risalah Jakarta salah satunya berbunyi pemerintah harus memimpin gerakan penguatan keberagamaan yang moderat sebagai arus utama, dengan mempromosikan pentingnya kehidupan beragama secara moderat sebagai panduan spiritual dan moral.

Dalam beberapa tahun terakhir, kecenderungan sikap intoleran kita kian menguat, baik secara internal umat beragama maupun secara eksternal. Kasus persekusi, pembakaran rumah ibadah, dan semua bentuk tindakan kekerasan kerap menjadi hal lumrah yang dikedepankan, tawuran antar pelajar menjadi wajah buram bagi institusi pendidikan kita. 
Misalnya, riset Maarif Institute (2011), Setara Institute (2015), dan Wahid Foundation (2016) menunjukkan bahwa kelompok-kelompok radikal telah secara masif melakukan penetrasi pandangan radikal di kalangan generasi muda melalui institusi pendidikan. Kemudian, diperkuat beberapa survei yang menunjukkan bahwa siswa maupun mahasiswa kecenderungan sikap intoleransi dan radikalisme cukup mengkhawatirkan, guru pun demikian. Gejala intoleransi dan radikalisme berbasis agama akan cenderung lebih besar daripada persoalan etnisitas. Kemudian intoleransi dan radikalisme juga terjadi dalam media sosial.

Dalam buku yang diterbitkan Maarif Institute, Menjaga Benteng Kebhinekaan di Sekolah, melihat ada tiga pintu utama bagaimana pemahaman radikal dan intoleransi melakukan penetrasi di lingkungan sekolah; pertama, kegiatan ekstrakurikuler. Kedua, peran guru dalam proses belajar mengajar. Ketiga, melalui kebijakan sekolah yang lemah dalam mengontrol masuknya radikalisme di sekolah. ${ }^{18}$ Jika kita melihat data dan temuan tersebut, kecenderungan intoleransi dan menguatnya radikalisme di sekolah sudah sangat memprihatinkan. Oleh karena itu, di sinilah letak strategisnya pengarusutamaan moderasi beragama perlu dilakukan.

Ruang sekolah sejatinya menjadi lahan tersemainya gagasan kebangsaan, menanamkan nilai-nilai multikulturalisme, membawa pesan agama dengan lebih damai, dan menebarkan cinta pada kemanusiaan. Hal itu mewujud dalam kurikulum yang berorientasi pada moderasi beragama.

Sekolah paling tidak menjadi ruang pengenalan antara NU dan Muhammadiyah, terutama sekolah-sekolah negeri dan sekolah swasta yang berafiliasi pada dua ormas tersebut.Sebetulnya, kita sudah memiliki modal sosial yang kuat, kemajemukan masyarakat menjadi potret bangsa kita.Nahdlatul Ulama (NU) dan Muhammadiyah sebagai organisasi Islam moderat di Indonesia perlu aktif mengambil peran sebab keduanya kalah pamor dengan ideologi transnasional yang menginginkan perubahan sistem politik Indonesia. 
Mereka lebih setia pada gerakan itu dan menafikan kemajemukan Indonesia, misalnya, berkeinginan untuk menjadikan Indonesia sebagai negara khilafah islamiah atau ada yang mengusung NKRI bersyariah. Kedua kelompok itu lupa bahwa kita sudah bersepakat pada Pancasila dan UUD 1945.

Ada beberapa langkah strategis yang bisa dijalankan pemerintah; pertama, moderasi beragama harus menjadi perhatian pemerintah dalam membuat narasi rencana pembangunan jangka panjang nasional(RPJPN), sebagai keseriusan pemerintah dalam menggaungkan moderasi beragama di kalangan umat beragama di Indonesia. Kedua, melibatkan lembaga pendidikan: pesantren, madarasah dan sekolah lebih juga perguruan tinggi lebih juga lembaga non formal lainnya dalam memperkuat nilainilai kemanusiaan, nilai-nilai kerukunan beragama, dan moderasi beragama. Ketiga, mengembangkan literasi keagamaan (religious literacy) dan pendidikan lintas iman (interfaith education). Keempat, sekolah mesti memperbanyak praktik pengalaman keagamaan yang berbeda sehingga kita bisa menjalin kerja sama antar pemeluk agama.

\section{Pendekatan Moderasi Sosio-Religius dalam Beragama dan Ber- negara}

Istilah moderasi sosio-religius merupakan sebentuk terjemahan dari konsep teoantroposentrik-integralistik. Artinya, yang kita tumbuhkembangkan bukan hanya tentang nilai dalam ajaran-ajaran agama, melainkan juga sekaligus tentang kepekaan-kepekaan sosial dalam kehidupan bernegara.Hubungan antara agama dan negara memang idealnya diposisikan saling berdampingan dan beriringan, bukan saling berhadap-hadapan.

Sebab, agama tidak sedang berupaya merebut otoritas bernegara, dan negara juga tidak sedang membatasi kehidupan beragama.Pada titik ini, kesadaran moderasi sosio-religius dalam beragama dan bernegara menjadi perspektif kita bersama untuk menegaskan bahwa 
pemberlakuan etika sosial adalah basis keberlangsungan kehidupan masyarakat multikultural.

Konsep moderasi sosio-religius dalam beragama sejatinya dapat dirumuskan deskripsinya berdasarkan Quran Surat Al-Anbiya ayat 107 yang artinya: «Dan tiadalah Kami mengutus kamu, melainkan untuk (menjadi) rahmat bagi semesta alam." Kita dapat menafsirkan kata rahmat dalam konteks kehidupan di dunia ini dengan moderasi dua pola relasi sekaligus.Pertama, rahmatan likulli 'aqilin.Artinya, kita harus senantiasa berbuat baik dan penuh kasih sayang kepada siapa saja. Rahmat kepada siapa saja.Rahmat sebagai sikap moderasi sosio-religius yang mengharuskan umat Islam berbuat baik kepada siapa saja telah dicontohkan Muhammad dalam peristiwa renovasi Kabah bersama para pemimpin suku Qurays. Sekitar lima tahun sebelum Muhammad menerima wahyu pertamanya, para pemimpin Qurays mengandalkan keputusannya yang adil untuk memecahkan persoalan yang sangat sensitif, yaitu siapakah yang paling berhak meletakkan batu hitam (hajar aswad) di tempatnya. Akhirnya, Muhammad diminta untuk memberikan solusi terbaiknya. Solusi jenius yang ditawarkan oleh Muhammad adalah dengan meletakkan batu hitam tersebut di atas sorbannya dan kemudian diangkat bersama-sama oleh semua pemimpin Qurays yang hadir di tempat itu.

Kedua, rahmatan likulli ghairi 'aqilin. Maksudnya adalah selain kepada siapa saja, kita juga harus bersikap rahmat kepada apa saja. Penafsiran dua model relasi rahmat (kepada siapa dan apa saja sekaligus) ini dapat dipertanggungjawabkan keabsahannya dengan menghadirkan buktibukti sikap rahmat yang telah dicontohkan oleh nabi Muhammad. Rahmat kepada apa saja, karena kita hidup tidak hanya dengan manusia, tetapi juga dengan lingkungan di sekitar kita. Oleh sebab itu, pemahaman terhadap kalimat rahmatan lil 'alamin harus juga sampai kepada apa saja yang berada di lingkungan kehidupan kita.Hal tersebut sebagaimana diperintahkan oleh Muhammad bahwa jangankan dalam keadaan damai, dalam keadaan perang sekalipun kita dilarang untuk merusak 
rumah-rumah ibadah kendati rumah-rumah ibadah tersebut milik umat non-Muslim.Bahkan juga menebang pohon sembarangan atau merusak sarana umum juga tidak diperkenankan.

\section{Penutup}

Moderasi Islam mengedepankan sikap keterbukaan terhadap perbedaan yang ada yang diyakini sebagai sunnatullah dan rahmat bagi manusia.Selain itu, moderasi Islam tercerminkan dalam sikap yang tidak mudah untuk menyalahkan apalagi sampai pada pengkafiran terhadap orang atau kelompok yang berbeda pandangan. Moderasi Islam lebih mengedepankan persaudaraan yang berlandaskan pada asas kemanusiaan, bukan hanya pada asas keimanan atau kebangsaan.

Oleh karena itu untuk mengaktualisasikan konsep moderasi beragama dalam konteks masyarakat multikultural: Pertama, menjadikan lembaga pendidikan sebagai basis laboratorium moderasi beragama. Lembaga pendidikan sangat tepat menjadi laboratorium moderasi beragama. Seperti yang telah dipahami bahwa bangsa Indonesia merupakan bangsa yang memiliki ragam suku dan agama. Indonesia memiliki kekhasan yang unik, tetapi penuh dengan tantangan. Adapun langkah strategisnya; 1) Moderasi beragama harus menjadi perhatian pemerintah dalam membuat narasi Rencana Pembangunan Jangka Panjang Nasional (RPJPN); 2) Melibatkan lembaga pendidikan: pesantren, madarasah dan sekolah maupun lembaga non formal lainnya dalam memperkuat nilai-nilai kemanusiaan, nilai-nilai kerukunan beragama, dan moderasi beragama; 3) Mengembangkan literasi keagamaan (religious literacy) dan pendidikan lintas iman (interfaith education); 4) Sekolah harus memperbanyak praktik pengalaman keagamaan yang berbeda sehingga dapat menjalin kerja sama antar pemeluk agama. Kedua, pendekatan moderasi sosio-religius dalam beragama dan bernegara. 


\section{Daftar Pustaka}

Al-Bukhari al-Ja'fi,Muhammad Ibn Ismail Abu Abdillah. 1978. Al-Jami alShagir al-Mukhtasar.juz. I, cet. III, Bairut: Dar ibn Katsir.

As-Sa'ud, Abu, Salah.2004. Al-Mu'tazilah; Nasyatuhu, Firaquhum, Arauhum al-Fikriyah. Al-Jazirah: Makbtabah al-Nafidzah

Auda, Jasser. 2013. Al-Maqasid Untuk Pemula. Yogyakarta: SUKA-Press.

Azra, Azyumardi. 2000. Renaisans Islam Asia Tenggara: Sejarah Wacana dan Kekuasaan. Bandung: Rosdakarya.

Darlis. 2017. Mengusung Moderasi Islam di Tengah Masyarakat Multikultural, Jurnal Rausyan Fikr,Vol. 13 No.2

Dhofier, Zamakhsyarir.1994. Tradi Pesantren; Studi Tentang Pandangan Hidup Kiai.Jakarta: LP3ES.

Hamid, Zainul, Ahmad.2007. NU dalam Persinggungan Ideologi: Menimbang Ulng Moderasi Keislaman Nahdatul Ulama. Afkar, Edisi No. 21.

Hasisah, Afifuddin. 2012. Islam: Eksklusivisme atau Inklusivisme? Menemukan Teologi Islam Moderat, dalam Kontruksi Islam Moderat. Yogyakarta: ICCAT Press.

https://kemenag.go.id.

Kamali, Hashim, Mohammad. 2015. The Middle Path of Moderation in Islam, Oxford University Press.

Ma'arif, Syafi'i, Ahmad. 2009. Islam dalam Bingkai Keindonesiaan dan Kemanusiaan; Sebuah Refleksi Sejarah. Bandung: Mizan.

Mas'ud, Abdurrahman. 2004. Intelektual Pesantren: Perhelatan Agama dan Tradisi. Yogyakarta: LKiS.

Mas'ud, Abdurrahman. 2006. Dari Haramain ke Nusantara: Jejak Intelektual Arsitek Pesantren. Jakarta: Kencana. 
Muhammad, Husein. 1999. Memahami Sejarah Ahlus Sunnah Waljamaah: Yang Toleran dan Anti Ekstrem, dalam Imam Baehaqi (ed.), Kontroversi Aswaja. Yogyakarta: LKiS.

Pranowo, Bambang. 1999. Islam Faktual: Antara Tradisi dan Relasi Kuasa. Yogyakarta: Adicita.

Prasetyo, Hendro. 1994. Mengislamkan Orang Jawa: Antropologi Baru Islam Indonesia. Islamika No.3

Qomar, Mujamil. 2002. NU Liberal; Dari Tradisionalisme Ahlusunnah ke Universalisme Islam. Bandung: Mizan.

Radwan Jamal el-Atrash dan Nahswan Abdo Khalid Qaid. 2011. al-Jazur al- Tarikhiyyah li al-Tafsir al-Maqashidi li al-Qur'an al-Karim, Majallah al-Islam fi Asiya, No. 1, Malaysia: UII.

Rahmat, M. Imdadun. 2003. (et al.). Islam Pribumi: Mendialogkan Agama Membaca Realitas. Jakarta: Erlangga.

Shihab, Alwi. 2007. Islam Inklusif: Menuju Sikap Terbuka dalam Beragama. Bandung: Mizan.

Shihab, Alwi. 1999. Islam Inklusif. Bandung: Mizan.

Shihab, M. Quraish. 2007. Secercah Cahaya Ilahi: Hidup Bersama AlQur'an. Bandung: Mizan.

Sholeh, Badrus. 2007. Budaya Damai Komunitas Pesantren. Jakarta: LP3ES

Siraj, Aqiel, Said. 2007. Tradisi dan Reformasi Keagamaan. Republika

Tim Penyusun Kementerian Agama RI,. 2019. Moderasi Beragama. Jakarta: Badan Litbang dan Diklat Kementerian Agama RI. 


\section{Endnotes}

1. Tim Penyusun Kementerian Agama RI, Moderasi Beragama, (Jakarta: Badan Litbang dan Diklat Kementerian Agama RI, 2019), h.16

2. Tim Penyusun Kementerian Agama RI, Moderasi Beragama, (Jakarta: Badan Litbang dan Diklat Kementerian Agama RI, 2019), h.29

3. Insan Khoirul Qolbi, LHS dan Moderasi Beragama, dalam www.kemenag. go.id. Diakses, 5 September 2019

4. Darlis, Mengusung Moderasi Islam di Tengah Masyarakat Multikultural, Jurnal Rausyan Fikr, Vol. 13 No.2 Desember 2017, h. 230-231

5. Mohammad Hashim Kamali, The Middle Path of Moderation in Islam (Oxford University Press, 2015), h.14

6. Mohammad Hashim Kamali, Op.,Cit, h.15

7. Masykuri Abdillah, Meneguhkan Moderasi Beragama, dalamhttp://graduate. uinjkt.ac.id/? $p=17325$

8. Masykuri Abdillah, Meneguhkan Moderasi Beragama, dalamhttp://graduate. uinjkt.ac.id/?p=17325

9. Tim Penyusun Kementerian Agama RI, Moderasi Beragama, (Jakarta: Badan Litbang dan Diklat Kementerian Agama RI, 2019), h. 18

10. Mustafa Syuk'ah, Al-Islam bila Madzahib, tth. h. 448.

11. Salah Abu As-Sa'ud, Al-Mu'tazilah; Nasyatuhu, Firaquhum, Arauhum alFikriyah, (Al-Jazirah: Makbtabah al-Nafidzah, 2004), h. 60.

12. Abd. Rauf Amin, Moderasi dalam Tradisi Pakar Hukum Islam(Wacana dan Karakteristik) dalam Kontruksi Islam Moderat, (Yokyakarta: ICATT Press, 2012), h. 73-77.

13. Radwan Jamal el-Atrash dan Nahswan Abdo Khalid Qaid, al-Jazur alTarikhiyyah li al-Tafsir al-Maqashidi li al-Qur'an al-Karim.Majallah al-Islam fi Asiya, No. 1 (Malaysia: UII, 2011), h. 220.

14. Jasser Auda, Al-Maqasid Untuk Pemula. (Yogyakarta: SUKA-Press, 2013), h. 299

15. Alwi Shihab, Islam Inklusif, (Bandung: Mizan, 1999), h.41

16. Afifuddin Harisah, Islam:Eksklusivisme atau Inklusivisme? Menemukan Teologi Islam Moderat, dalam Kontruksi Islam Moderat, (Yogyakarta: ICCAT Press, 2012), h.43

17. Darlis, Mengusung Moderasi Islam di Tengah Masyarakat Multikultural, Jurnal Rausyan Fikr, Vol. 13 No.2 Desember 2017, h. 247-248

18. Dirga Maulana, Ruang Moderasi Beragama dalam http://mediaindonesia. com,Tanggal 21 Januari 2019. 